\title{
Pengembangan Layanan Taman Penitipan Anak Holistik Integratif Berbasis Alam
}

\author{
Suparmiati $^{1}{ }^{凶}$, Lita Latiana $^{1}$, Kustiono $^{1}$ \\ Pendidikan Anak Usia Dini, Universitas Negeri Semarang, Indonesia(1) \\ DOI: $10.31004 /$ obsesi.v6i4.2269
}

\begin{abstract}
Abstrak
Era globalisasi sekarang ini banyak kedua orang tua yang sibuk bekerja, akhirnya orang tua harus mempertimbangkan alternatif pengasuhan bagi anak selama mereka bekerja. Penelitian ini bertujuan untuk menganalisis pelaksanaan layanan Program Holistik Integratif TPA di Kabupaten Rembang yang meliputi layanan pendidikan, pengasuhan, kesehatan, gizi serta perlindungan. Penelitian ini menggunakan metode RnD. Subjek penelitian ini adalah TPA Tunas Pertiwi yang berlokasi di Sumber Rembang. Sumber data penelitian ini menggunakan dua sumber data yaitu sumber data primer pengelola, pengasuh dan orang tua siswa, sedangkan data sekunder dalam bentuk dokumen-dokumen. Dalam penelitian ini analisis data menggunakan analisa dekriptif kualitatif dan kuantitatif. Hasil penelitian menunjukkan kualitas Model Layanan TPA HI Berbasis Alam cukup memadai. Hal tersebut nampak pada hasil penilaian dari ke empat validator yang menunjukkan bahwa scor penilaian rata-rata sebesar 73,33\%. Buku Panduan yang penulis kembangkan juga sudah memadai, berdasarkan penilaian para validator mengenai buku panduan TPA HI berbasis alam diperoleh skor $86,4 \%$.
\end{abstract}

Kata Kunci: holistik integratif; layanan; tpa.

\begin{abstract}
In the current era of globalization, many parents are busy working, finally parents have to consider alternative care for their children while they are working. This study aims to analyze the implementation of the TPA Integrative Holistic Program in Rembang Regency which includes education, care, health, nutrition and protection services. This study uses the RnD method. The subject of this research is TPA Tunas Pertiwi which is located in Sumber Rembang. The data sources of this study used two data sources, namely primary data sources for managers, caregivers and parents of students, while secondary data in the form of documents. In this study, data analysis used qualitative and quantitative descriptive analysis. The results showed that the quality of the Nature-Based TPA HI Service Model was adequate. This can be seen in the results of the assessment of the four validators which show that the average score is $73.33 \%$. The guidebook that the author has developed is also adequate, based on the validators' assessment of the nature-based TPA HI guidebook, a score of $86.4 \%$ was obtained.
\end{abstract}

Keywords: tpa services; integrative holistic; integrative holistic tpa

Copyright (c) 2021 Suparmiati, et al.

$\triangle$ Corresponding author :

Email Address : suparmiati@students.unnes.ac.id (Rembang, Jawa Tengah, Indonesia)

Received 11 November 2021, Accepted 8 Februari 2022, Published 13 February 2022 


\section{PENDAHULUAN}

Era globalisasi kian bergerak cepat seiring perkembangan zaman, dimana tuntutan kebutuhan bergeser lebih tinggi, sudah tidak zamannya lagi bahwa hanya suami yang mencari nafkah. Sekarang ini, kesempatan kerja bagi perempuan pun semakin meningkat sehingga laki-laki dan perempuan memiliki kesempatan yang sama dalam mengakses dan mendapatkan pekerjaan. Semula memang istri hanya disibukkan dengan segala urusan domestik yang berhubungan dengan urusan rumah tangga dan pengasuhan anak saja. Namun, istri kini juga mulai memasuki ranah publik dengan bekerja keluar rumah untuk mencari penghasilan tambahan (Rizkita, 2017).

Keberadaan orang tua yang keduanya memutuskan untuk bekerja kini sudah sangat lumrah dan tidak di anggap aneh lagi. Namun bukan hal yang tidak dapat dipungkiri dan bahkan dapat membentuk sebuah perasaan bersalah dalam diri orang tua, manakala orang tua yang keduanya bekerja yang pada akhirnya harus meninggalkan anak-anaknya sementara selama mereka bekerja. Mereka memang dapat memiliki penghasilan lebih untuk memenuhi berbagai kebutuhan. Penghasilan yang lebih pun dapat ditabung apabila ada keperluan mendadak. Tetapi di sisi lain kesibukan aktivitas orang tua dapat menimbulkan persoalan, terutama dalam hal pengasuhan anak, di mana anak tersebut ditinggalkan oleh orang tuanya selama mereka bekerja dan menyebabkan kurangnya pemenuhan kebutuhan pengasuhan bagi anak (Kamtini, 2015).

Anak dalam masa proses tumbuh dan kembangnya masih sangat membutuhkan peranan dari orang tua dalam kehidupannya. Peranan dari orang tua pada dasarnya mengarahkan anak-anak sebagai generasi unggul, karena potensi anak tidak akan tumbuh dengan sendirinya tanpa dukungan dan bantuan dari orang tua. Beberapa orang tua pergi bekerja ketika matahari mulai terbit dan pulang ketika matahari sudah terbenam, sehingga mereka hanya bisa menemani anaknya setelah rutinitas di luar rumah, itu pun hanya dengan hitungan jam per hari. Hal ini semakin menambah kurang terjalinnya komunikasi antara orang tua dan anak, si anak pun merasa kurang perhatian dan kasih sayang dari orang tuanya. Pada akhirnya orang tua harus mempertimbangkan alternatif wahana pengasuhan bagi anak selama dirinya tengah melakukan aktivitas kerjanya tersebut, yang nantinya dapat menjadi keluarga pengganti sementara dan menggantikan peran orang tua dalam hal mengasuh, merawat, dan melindungi anaknya. Selain itu, dapat mendidik agar anak terhindar dari stagnasi proses tumbuh dan kembangnya. Untuk menghindari timbulnya dampak negatif tersebut, maka orang tua sepakat untuk menitipkan anaknya di tempat yang layak agar mereka dapat bekerja dengan tenang tanpa merasa takut akan kondisi anaknya selama bekerja (Hamdiani dkk, 2016)

Dengan pertimbangan inilah orang tua mempercayakan anaknya untuk diasuh di TPA sebagai pengganti keluarga sekaligus wahana alternatif pengasuhan bagi anak yang orang tuanya sibuk bekerja. TPA adalah salah satu bentuk PAUD jalur pendidikan non formal yang menyelenggarakan program pendidikan sekaligus pengasuhan dan kesejahteraan anak sejak lahir sampai dengan usia 6 tahun. Day Care atau Child Care atau Family Child Care merupakan istilah lain dari TPA. Day Care adalah sarana pengasuhan anak yang biasanya dilaksanakan saat jam kerja. Pelayanan ini diberikan dalam bentuk peningkatan gizi, pengembangan intelektual, emosional dan sosial (Lestari dkk, 2018).

Sekarang ini, TPA menjadi salah satu alternative tempat bagi kedua orang tua yang sibuk bekerja untuk menitipkan anaknya yang masih berusia balita. di TPA, anak-anak ditanamkan pada nilai-nilai hidup sehat, pemberian makanan bergizi, kebiasaan nilai-nilai kesetiakawanan sosial atau berbagai bentuk-bentuk permainan pada anak-anak yang dititipkan. Kegiatan-kegiatan tersebut bertujuan agar anak-anak tetap terjaga dan terjamin pertumbuhan dan perkembangan sesuai dengan jiwa dan kepribadiannya (Supsiloani, Puspitawati, 2015) TPA merupakan salah satu pilihan alternatif bagi orang tua karier yang selalu menginginkan yang terbaik akan perkembangan anak-anak mereka. 
Beberapa TPA juga menawarkan berbagai program kegiatan anak yang sudah terstruktur sehingga menjadi daya tarik tersendiri bagi orang tua untuk untuk mengasuh anaknya di TPA. Umumnya, TPA hanya memberikan layanan kepada anak usia dini secara terbatas periode waktu. Permendikbud No 137 Tahun 2014 tentang Standar Nasional Pendidikan Anak Usia Dini selanjutnya disebut standar PAUD adalah kriteria tentang pengelolaan dan penyelenggaraan PAUD diseluruh wilayah hukum Negara Kesatuan Republik Indonesia. Standar Pengelolaan adalah kriteria tentang perencanaan, pelaksanaan, dan pengawasan kegiatan pendidikan pada tingkat satuan atau program PAUD. Manajemen yang efektif dan efisien pada TPA sangat diperlukan agar nantinya kebutuhan anak untuk mendapatkan pelayanan pendidikan tetap terlaksana sesuai dengan tumbuh dan kembang anak, meskipun orang tua sibuk bekerja (Chairilsyah, 2017).

Sehingga pada tahun 2013 pemerintah telah diatur dalam Peraturan Presiden no. 60 lebih awal perkembangan masa kecil melalui pendekatan"Integrative Holistic", yaitu Anak Usia Dini tidak hanya menekankan aspek pendidikan saja, tetapi mencakup aspek layanan gizi, kesehatan perawatan, pengasuhan anak, dan perlindungan anak. Dengan pendekatan ini, anak dapat memperoleh pendidikan layanan utuh, kontinuitas dan kualitas serta penggunaan sumber daya energi yang lebih efisien,dana, fasilitas dan infrastruktur yang dibutuhkan (Java, 2014).

Holistik berarti seluruh kebutuhan anak (kesehatan, gizi, pendidikan, perlindungan, berkembang dan mempertahankan kelangsungan hidup) dilayani dalam lembaga penyelenggara TPA. Integratif berarti semua lembaga TPA melakukan koordinasi dengan instansi-instansi Pembina. Selain itu, TPA juga dapat membantu anak dalam memperoleh lingkaran persabahatan yang lebih besar, yang mana anak akan lebih aman dapat menempatkan sebanyak-banyaknya perhatian anak dari lingkungan luar rumah (Khasanah, 2017). Semakin banyaknya lembaga penitipan anak tidak menjamin bahwa semua lembaga tersebut memberikan layanan yang sesuai dengan kebutuhan anak dan sesuai dengan petunjuk teknis penyelenggaraan yang sesuai dari pemerintah. Adapun layanan yang diberikan oleh lembaga penitipan anak pada umumnya meliputi layanan pengasuhan, pendidikan, kesehatan dan gizi serta pemberian fasilitas sesuai dengan kebutuhan tumbuh kembang anak, sehingga pertumbuhan dan perkembangan anak dapat terlayani dengan seimbang.

Dalam penyelenggaraan TPA yang masih konvensional, sebagian besar kegiatan pembelajaran anak masih berada di dalam kelas dengan tembok, dengan bahan ajar/sumber ajar yang masih konvensional seperti buku dan lembar kerja siswa. Bahan ajar yang sudah biasa ditambah dengan metode penyampaian yang kurang menarik membuat anak sering merasa jenuh pada pembelajaran yang demikian.

Pembelajaran berbasis alam adalah pandangan bahwa kegiatan pembelajaran dapat membantu anak mengembangkan berbagai potensi perkembangan yang dipergunakan untuk beradaptasi secara kreatif dengan lingkungan alam. Kegiatan pembelajaran menggunakan lingkungan alam dengan variasi untuk memenuhi kebutuhan perkembangan anak usia dini. Pembelajaran berbasis alam akan membantu menumbuhkan otoaktivitas dan autoactivity (aktivitas yang tumbuh dari dalam diri) anak sehingga dimungkinkan terjadi proses active learning (belajar secara aktif). Lingkungan alam akan memberikan sejumlah pengalaman belajar langsung (real learning) dan atau pembelajaran secara nyata (real instructions). Konsep pembelajaran berbasis alam akan memberikan suasana atau kesempatan pada anak untuk mengembangkan kepekaan, kepedulian atau sensitivitas terhadap berbagai kondisi lingkungan alam. Pembelajaran berbasis alam akan membantu anak memperoleh proses dan hasil belajar yang bermakna (meaningfull learning) serta pembelajaran yang fungsional praktis (practical and functional intruction). Melalui pembelajaran berbasis alam, anak dapat menemukan, memahami dan menerapkan secara langsung proses belajar pada berbagai aspek dalam kehidupan secara nyata. Dengan demikian, anak dapat memaknai bahwa belajar tentang berbagai hal akan memiliki makna dalam kehidupan kini maupun di masa yang akan 
datang (Septiani Nifa, 2016). Sama halnya dilakukan oleh (Aprilia \& Trihantoyo, 2018) dalam penelitiannya menyebutkan bahwa model pembelajaran berbasis alam dalam membentuk karakter siswa cinta lingkungan dan berbasis religi islami meliputi: (1) penyusunan model pembelajaran berbasis alam. (2) model pembelajaran yang digunakan yaitu model belajar bersama alam (BBA), model kooperatif kelompok, model kontektual, model inkuiri, dan model eksperimen, (3) evaluasi model pembelajaran dilakukan setiap satu minggu sekali untuk memperbaiki proses belajar mengajar.

Kabupaten Rembang merupakan wilayah yang berada di ujung timur Provinsi Jawa Tengah dan perbatasan dengan Provinsi Jawa Timur. Banyak kekayaan alam yang terdapat di Kabupaten Rembang, seperti laut, hutan, kebun, sawah, bahkan pegunungan. Banyak pula terdapat perkantoran dan pabrik saat ini, sehingga banyak pula para pekerja-pekerja, termasuk para istri yang bekerja mencarai tambahan penghasilan, sehingga banyak pula bermunculan lembaga yang menawarkan pengasuhan bagi para orang tua yang sibuk bekerja. Menurut data dari Dinas pendidikan Pemuda dan Olahraga Kabupaten Rembang, jumlah layanan TPA yang ada di Kabupaten Rembang saat ini berjumlah 20 layanan Taman Penitipan Anak TPA yang masing-masing tersebar dibeberapa wilayah kecamatan se- Kabupaten Rembang, dan yang paling banyak jumlahnya adalah di Kecamatan Rembang kota.

Berdasarkan fenomena di atas peneliti tertarik untuk melakukan riset tentang bagaimana kondisi real TPA di Kabupaten rembang dalam melaksanakan program Holistik Integratif.

\section{METODOLOGI}

Penelitian ini menggunakan pendekatan penelitian dan pengembangan research and development (R\&D) yang diadaptasikan dari model pengembangan Borg \& Gall (2003). Research and development ini menggunakan kualitiatif untuk mengetahui validitas rasional dari produk yang dihasilkan. Metode penelitian dan pengembangan merupakan metode yang digunakan untuk menghasilkan produk tertentu. Langkah-langkah penelitian pengembangan dalam penelitian ini disederhanakan menjadi tujuh Langkah dikarenakan keterbatasan waktu dan biaya oleh penguji. Langkah yang harus ditempuh yaitu: (1) potensi dan masalah, (2) pengumpulan data, (3) desain produk, (4) validasi desain, (5) revisi desain, (6) uji coba produk, (7) revisi produk. Penyederhanaan ini dilakukan dengan pertimbangan untuk menyelaraskan dengan tujuan khusus penelitian yang terbagi ke dalam tiga tahap kegiatan penelitian. Berikut ini disajikan skema prosedur pengembangan model layanan Taman penitipan Anak (TPA) holistik integgratif berbasis alam.

Penyederhanaan ini dilakukan dengan pertimbangan untuk menyelaraskan dengan tujuan khusus penelitian yang terbagi ke dalam tiga tahap kegiatan penelitian. Tahap pertama, yaitu penelitian pendahuluan, meliputi: (1) menganalisis potensi dan masalah, (2) pengumpulan data lapangan dan identifikasi masalah, serta menganalisis kebutuhan. Tahap kedua, pengembangan, meliputi: (1) penyusunan draf/desain produk, (2) validasi desain produk, (3) revisi desain. Tahap ketiga, yaitu uji coba produk, meliputi kegiatan: (1) uji coba produk, (2) revisi produk dan penyusunan produk final, yaitu buku panduan penyelenggaraan Taman Penitipan Anak (TPA) Holistik Integratif berbasis alam. Gambar 1 disajikan skema prosedur pengembangan model layanan Taman penitipan Anak (TPA) holistik integgratif berbasis alam.

Subyek dalam penelitian ini adalah Sekolah yang akan digunakan sebagai sumber data dalam penelitian ini ditentukan melalui purposive sampling, Dasar yang digunakan sebagai pertimbangan dalam pemilihan sampel sumber data pada penelitian ini adalah Taman Penitipan Anak Tunas Pertiwi yang berlokasi di Kecamatan Sumber Rembang. Dasar pertimbangan pemilihan sampel di Taman Penitipan Anak (TPA) Tunas Pertiwi karena jarak lokasi yang dekat dengan tempat tinggal peneliti. Desain uji coba menggunakan preexperimental design (Non Desaign) dengan bentuk One-Shoot Case Study. Teknik 
pengumpulan data yang digunakan dalam penelitian ini adalah wawancara, angket, observasi, dokumentasi dan Observasi.

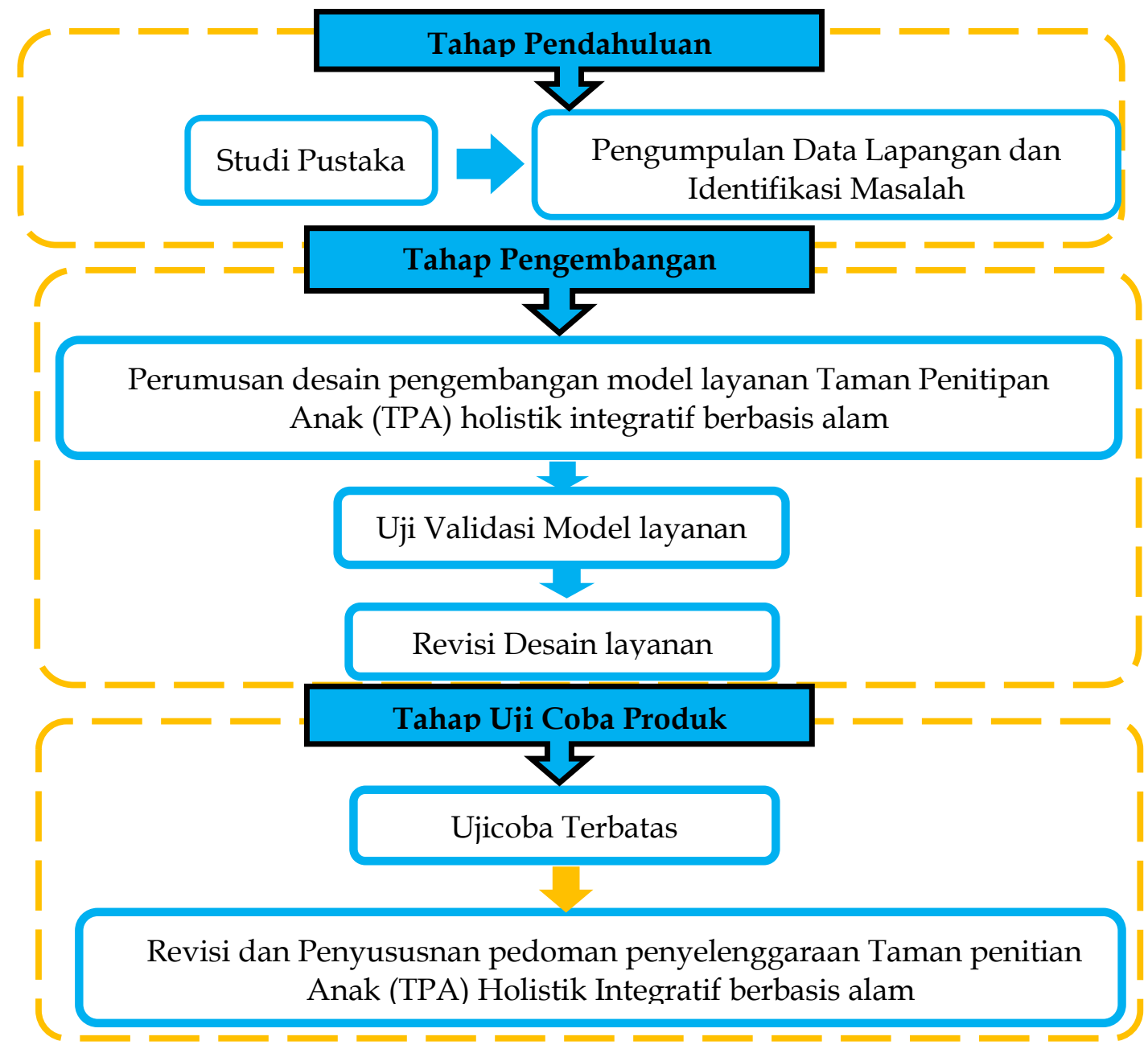

Gambar 1 Skema Prosedur Pengembangan

\section{HASIL DAN PEMBAHASAN}

Hasil pengembangan yang dilakukan pada penelitian ini adalah menghasilkan model Taman Penitipan Anak (TPA) Holistik integratif Berbasis Alam dan media pembelajaran berupa buku panduan layanan Taman Penitipan Anak (TPA) holistik integratif berbasis alam. Penelitian diawali dengan survey awal yang melibatkan 20 pengelola TPA di Kabupaten Rembang sebagai responden. Berdasarkan data bahwa saat ini dari 20 lembaga TPA di Kabupaten Rembang ada 17 TPA yang pelayanannya belum memenuhi standart layanan Taman Penitipan Anak sesuai dengan petunjuk teknis penyelenggaraan Taman Penitipan Anak dari pemerintah melalui Direktorat Pembinaan Pendidikan Anak Usia Dini dan Pendidikan Masyarakat tahun 2015. Berdasarakan data Lembaga yang belum terakreditasi Terdapat 11 TPA diantaranya cenderung kepada Taman Penitipan Anak murni atau Taman Penitipan Anak (TPA) yang hanya melayani pengasuhan dan pendidikan anak saja, itupun pendidikan yang dilaksanakan belum secara menyeluruh, beberapa diantaranya belum membuat perencanaan pembelajaran dan mengevaluasi hasil perkembangan anak secara maksimal. Pelayanan dan pengasuhan anak yang kurang maximal akan mempengaruhi tumbuh kembang anak yang kurang optimal.

Pelayanan pengembangan anak usia dini secara holistik integratif dilakukan dalam rangka memenuhi kebutuhan-kebutuhan dasar anak yang meliputi kebutuhan kesehatan dan gizi, pendidikan dan stimulasi serta kasih sayang orang tua. Secara umum kebutuhan 
dasar anak meliputi kebutuhan fisik-biomedis (asuh), emosi/ kasih sayang (asih), dan kebutuhan akan stimulasi mental (asah). Sarana dan prasarana berkaitan dengan lahan dan bangunan basis pelayanan terpadu dengan pendekatan Holistik Integratif. Bangunan tempat pelayanan sesuai dengan fungsi setiap jenis pelayanan, ruang rawat, ruang periksa, kamar tidur, sesuai standar minimum masing-masing pelayanan, lahan bermain (play ground), taman bermain dan perpustakaan. Sarana bermain seperti APE (Alat Permainan Edukatif), alat bermain di dalam dan luar ruangan, sarana belajar seperti kurikulum, buku, materi bahan ajar, peralatan, furniture, sarana kesehatan seperti buku KIA (Kesehatan Ibu dan Anak), KMS (Kartu Menuju Sehat) dan lain - lain, dan sarana pembekalan kesehatan seperti vaksin, obat, suplementasi gizi mikro.

Dari hasil Survey awal diatas penulis membuat model layanan TPA Holistik Integratif Berbasis Alam untuk memfasilitasi layanan TPA secara Holistik dengan memanfaatkan Aset Sumber daya alam yang ada di sekitar TPA. Uji coba produk berupa model layanan TPA HI berbasis alam dilakukan dengan 2 cara yaitu: ujicoba kelompok kecil dan uji lapangan.

Pada ujicoba kelompok kecil dilakukan dengan memberikan angket kepada 5 responden di TPA Tunas Pertiwi Sumber Rembang, yaitu 4 guru PAUD dan 1 Kepala Sekolah dengan cara memberikan tanda checklist $(\sqrt{ })$ pada kolom nilai (angka 1, 2, 3, 4 atau 5) sesuai dengan kriteria 1: Sangat kurang baik/sangat kurang tepat/sangat kurang jelas, 2 : kurang baik/kurang tepat/kurang jelas, 3: cukup baik/cukup tepat/cukup jelas, 4: baik/tepat/jelas, 5: sangat baik/sangat tepat/sangat jelas. Terdapat 25 indikator yang dinilai, dengan skor maximal 125 dan skor minimal 25, sebagaimana disajikan pada tabel 1 . Hasil rekapitulasi respon peserta didik di tiga sekolah tersebut dapat dilihat pada tabel 2.

Berdasarkan tabel 2 hasil ujicoba kelompok kecil dengan memberikan 6 pernyataan kepada 5 guru sebagai responden sesuai masing-masing aspek, diperoleh skor persentase tiap aspek aspek struktur model sebesar $76 \%$, aspek kesesuaian isi sebesar $72 \%$, aspek kesesuaian konstruk sebesar $72 \%$, aspek bahasa sebesar 76\%, aspek tingkat kepraktisan sebesar $68 \%$, dan aspek organisasi penulisan sebesar $76 \%$ dikategorikan setuju, sehingga diperoleh skor ratarata untuk semua aspek yaitu 73,33\% dengan kategori setuju.

Tabel 1. Indikator Penilaian oleh validator

\begin{tabular}{clll}
\hline Nilai & \multicolumn{1}{c}{ Skor } & \multicolumn{1}{c}{ kualifikasi } & \multicolumn{1}{c}{ keteragan } \\
\hline A & $100 \leq x \leq 125$ & Sangat Baik & Dapat digunakan tanpa revisi \\
B & $86 \leq x \leq 105$ & Baik & Dapat digunakan dengan sedikit revisi \\
C & $66 \leq x \leq 85$ & Cukup & Dapat digunakan dengan banyak revisi \\
D & $46 \leq x \leq 65$ & Kurang & Harus dikonsultasikan lagi \\
E & $25 \leq x \leq 45$ & Sangat Kurang & Tidak dapat digunakan \\
\hline
\end{tabular}

Tabel 2. Hasil Rekapitulasi Ujicoba Kelompok Kecil

\begin{tabular}{clcc}
\hline No & \multicolumn{1}{c}{ Aspek } & Prosentase (\%) Keidealan & Kategori \\
\hline 1 & Struktur model & $76 \%$ & Setuju \\
2 & Kesesuaian isi & $72 \%$ & Setuju \\
3 & Kesesuaian konstruk & $72 \%$ & Setuju \\
4 & Bahasa & $76 \%$ & Setuju \\
5 & Tingkat kepraktisan & $68 \%$ & Setuju \\
6 & Organisasi penulisan & $76 \%$ & Setuju \\
\hline & Total aspek & $73,33 \%$ & Setuju \\
\hline
\end{tabular}

Setelah melakukan ujicoba kelompok kecil, kemudian produk diujicobakan kembali ke ujicoba lapangan. Hal ini dilakukan untuk meyakinkan data dan mengetahui produk secara luas, dengan jumlah responden keseluruhan sebanyak 20 responden, dan masing-masing sekolah terdiri 5 responden. Uji coba lapangan dilakukan dengan cara memberi angket untuk 
mengetahui respon guru terhadap buku panduan TPA HI berbasis alam. Adapun hasil ujicoba lapangan di 4 PAUD HI, sebagaimana pada tabel 3.

Tabel 3. Hasil Ujicoba Lapangan TPA A

\begin{tabular}{clcl}
\hline No & \multicolumn{1}{c}{ Aspek } & $\begin{array}{c}\text { Prosentase (\%) } \\
\text { Keidealan }\end{array}$ & Kategori \\
\hline 1 & Struktur model & $92 \%$ & Sangat Setuju \\
2 & Kesesuaian isi & $88 \%$ & Sangat Setuju \\
3 & Kesesuaian konstruk & $88 \%$ & Sangat Setuju \\
4 & Bahasa & $84 \%$ & Sangat Setuju \\
5 & Tingkat kepraktisan & $92 \%$ & Sangat Setuju \\
6 & Organisasi penulisan & $88 \%$ & Sangat Setuju \\
\hline \multicolumn{2}{r}{ Total aspek } & $88,67 \%$ & Sangat Setuju \\
\hline
\end{tabular}

Berdasarkan table 3. hasil ujicoba lapangan TPA A, diperoleh skor persentase tiap aspek, aspek struktur model sebesar $92 \%$, aspek kesesuaian isi sebesar $88 \%$, aspek kesesuaian konstruk sebesar $88 \%$, aspek bahasa sebesar $84 \%$, aspek tingkat kepraktisan sebesar $92 \%$, dan aspek organisasi penulisan sebesar $88 \%$. Secara keseluruhan, diperoleh total skor rata-rata untuk semua aspek yaitu $88,67 \%$ dengan kategori sangat setuju.

Tabel 4. Hasil Ujicoba Lapangan TPA B

\begin{tabular}{clcl}
\hline No & \multicolumn{1}{c}{ Aspek } & $\begin{array}{c}\text { Prosentase (\%) } \\
\text { Keidealan }\end{array}$ & Kategori \\
\hline 1 & Struktur model & $96 \%$ & Sangat Setuju \\
2 & Kesesuaian isi & $92 \%$ & Sangat Setuju \\
3 & Kesesuaian konstruk & $80 \%$ & Setuju \\
4 & Bahasa & $88 \%$ & Sangat Setuju \\
5 & Tingkat kepraktisan & $96 \%$ & Sangat Setuju \\
6 & Organisasi penulisan & $88 \%$ & Sangat Setuju \\
\hline \multicolumn{2}{r}{ Total aspek } & $90 \%$ & Sangat Setuju \\
\hline
\end{tabular}

Berdasarkan tabel 4 hasil ujicoba lapangan TPA B, diperoleh skor persentase tiap aspek, aspek struktur model sebesar $96 \%$, aspek kesesuaian isi sebesar $92 \%$, aspek kesesuaian konstruk sebesar $80 \%$, aspek bahasa sebesar $88 \%$, aspek tingkat kepraktisan sebesar $96 \%$, dan aspek organisasi penulisan sebesar $88 \%$. Secara keseluruhan, diperoleh total skor rata-rata untuk semua aspek yaitu 90\% dengan kategori sangat setuju.

Tabel 5. Hasil Ujicoba Lapangan TPA C

\begin{tabular}{clcc}
\hline No & \multicolumn{1}{c}{ Aspek } & $\begin{array}{c}\text { Prosentase (\%) } \\
\text { Keidealan }\end{array}$ & Kategori \\
\hline 1 & Struktur model & $96 \%$ & Sangat Setuju \\
2 & Kesesuaian isi & $80 \%$ & Setuju \\
3 & Kesesuaian konstruk & $92 \%$ & Sangat Setuju \\
4 & Bahasa & $88 \%$ & Sangat Setuju \\
5 & Tingkat kepraktisan & $80 \%$ & Setuju \\
6 & Organisasi penulisan & $92 \%$ & Sangat Setuju \\
\hline \multicolumn{2}{r}{ Total aspek } & $88,00 \%$ & Sangat Setuju \\
\hline
\end{tabular}

Berdasarkan tabel 5. hasil ujicoba lapangan TPA C, diperoleh skor persentase tiap aspek, aspek struktur model sebesar $96 \%$, aspek kesesuaian isi sebesar $80 \%$, aspek kesesuaian konstruk sebesar $92 \%$, aspek bahasa sebesar $88 \%$, aspek tingkat kepraktisan sebesar $80 \%$, dan 
aspek organisasi penulisan sebesar 92\%. Secara keseluruhan, diperoleh total skor rata-rata untuk semua aspek yaitu 88\% dengan kategori sangat setuju. Berdasarkan table 5. hasil ujicoba lapangan TPA C, diperoleh skor persentase tiap aspek, aspek struktur model sebesar 96\%, aspek kesesuaian isi sebesar $88 \%$, aspek kesesuaian konstruk sebesar 92\%, aspek bahasa sebesar $84 \%$, aspek tingkat kepraktisan sebesar $76 \%$, dan aspek organisasi penulisan sebesar $80 \%$. Secara keseluruhan, diperoleh total skor rata-rata untuk semua aspek yaitu $86 \%$ dengan kategori sangat setuju.

Tabel 5. Hasil Ujicoba Lapangan TPA D

\begin{tabular}{clcl}
\hline No & \multicolumn{1}{c}{ Aspek } & $\begin{array}{c}\text { Prosentase (\%) } \\
\text { Keidealan }\end{array}$ & \multicolumn{1}{c}{ Kategori } \\
\hline 1 & Struktur model & $96 \%$ & Sangat Setuju \\
2 & Kesesuaian isi & $88 \%$ & Sangat Setuju \\
3 & Kesesuaian konstruk & $92 \%$ & Sangat Setuju \\
4 & Bahasa & $84 \%$ & Sangat Setuju \\
5 & Tingkat kepraktisan & $76 \%$ & Setuju \\
6 & Organisasi penulisan & $80 \%$ & Setuju \\
\hline & Total aspek & $86,00 \%$ & Sangat Setuju \\
\hline
\end{tabular}

Secara keseluruhan tanggapan angket uji coba lapangan masing-masing TPA adalah TKA (88,67\%), TKB (90\%), TKC (88\%), TKD (86\%). Sehingga, secara keseluruhan rata-rata respon guru PAUD terhadap buku panduan TPA HI adalah sebesar 88,16\% dalam kategori interpretasi sangat setuju. Setelah dilakukan ujicoba kelompok kecil dan ujicoba lapangan, dilakukan revisi produk untuk kesempurnaan buku panduan model TPA HI berbasis alam. Sehingga, dapat digunakan sebagai pegangan guru dan pengelola TPA HI berbasis alam yang dapat membantu proses pembelajaran dengan baik dan maksimal.

\section{Pembahasan}

Penelitian dan pengembangan didefinisikan sebagai studi sistematis terhadap pengetahuan ilmiah yang lengkap atau pemahaman tentang subjek yang diteliti. Penelitian ini diklasifikasikan sebagai dasar atau terapan sesuai dengan tujuan peneliti yaitu untuk mengembangkan model panduan pembelajaran berupa buku panduan layanan TPA HI berbasis alam. Untuk menghasilkan model panduan pembelajaran tersebut, maka peneliti menggunakan prosedur penelitian pengembangan Borg and Gall yang hanya dibatasi sampai tujuh langkah penelitian dan pengembangan, yaitu potensi dan masalah, pengumpulan data, desain produk, validasi desain, perbaikan desain, ujicoba produk, revisi produk.

Alasan peneliti membatasi hanya sampai tujuh langkah, karena ketujuh langkah tersebut telah menjawab rumusan masalah, dan peneliti juga melakukan beberapa penyesuaian dengan kondisi dan kebutuhan peserta didik dalam mengadaptasi proses dari pengembangan model panduan pembelajaran yang akan dibuat. Meskipun dengan melakukan tujuh tahapan dari prosedur penelitian dan pengembangan Borg and Gall, proses ini tetap melakukan tahapan dasar dari metode penelitian dan pengembangan, yaitu: analisis kebutuhan, campur tangan ahli untuk memvalidasi produk, dan ujicoba produk untuk mengetahui respon guru dan pengelola TPA HI terhadap produk yang dikembangkan. Hal ini dikarenakan model penelitian Borg and Gall menyatakan bahwa prosedur penelitian dan pengembangan terdiri dari dua tujuan utama, yaitu: (1) mengembangkan produk, dan (2) menguji keefektifan produk dalam mencapai tujuan.

Hasil validasi dilakukan oleh 2 validator ahli, yaitu 1 praktisi TPA dan 1 pakar dosen ahli. Kedua validator melakukan penilaian pada tahap awal secara terpisah dengan nilai keseluruhan sebesar $78 \%$ oleh praktisi dan $75 \%$ oleh dosen ahli, dan rata-rata dari kedua validator tahap awal sebesar 76,5\%, sehingga mencapai kategori interpretasi "Baik". Selanjutnya, kedua validator juga melakukan penilaian pada tahap akhir dengan nilai keseluruhan sebesar $86,4 \%$ oleh praktisi dan $88,8 \%$ oleh dosen ahli, dan rata-rata dari kedua 
validator tahap awal sebesar $87,6 \%$, sehingga mencapai kategori interpretasi "Sangat Baik". Hal ini menunjukkan bahwa terdapat peningkatan rata-rata hasil validasi sebesar $11,1 \%$.

Penelitian ini juga diujicobakan melalui dua tahap yaitu ujicoba kelompok kecil dan ujicoba lapangan. Secara keseluruhan, hasil rata-rata ujicoba kelompok kecil diperoleh nilai sebesar yaitu 73,33\% dan dengan kategori interpretasi setuju. Adapun hasil rata-rata ujicoba lapangan diperoleh nilai yang berbeda-beda, yaitu 1) pada TKA sebesar 88,67\% dengan kategori interpretasi sangat baik, 2) pada TKB sebesar $90 \%$ dengan kategori interpretasi sangat baik, 3) pada TKA sebesar $88 \%$ dengan kategori interpretasi sangat baik, 4) pada TKD sebesar 86\% dengan kategori interpretasi sangat baik. Sehingga hasil keseluruhan sebesar 88,16 dengan kategori interpretasi sangat baik. Oleh karenanya, produk akhir dinilai sangat baik dan siap digunakan sebagai buku panduan layanan TPA HI dalam proses pembelajaran.

Alasan mendasar munculnya buku panduan TPA HI karena tingkat kemampuan guru yang berbeda-beda dalam mempersiapkan materi, sarana prasarana pembelajaran di kelas serta keterbatasan waktu guru dalam memanfaatkan ketersediaan fasilitas serta kurangnya komunikasi dengan berbagai instansi di sekitar TPA, maka peneliti berminat mengembangkan model layanan berupa buku panduan TPA HI berbasis alam, yang memungkinkan dapat membantu guru dalam memaksimalkan fasilitas yang ada di sekitar TPA secara integral dan komprehensif. Rendahnya wawasan sebagian guru PAUD juga menjadi alasan mengembangkan buku panduan TPA HI berbasis alam, sehingga menambah khasanah keilmuan bagi para guru untuk memanfaatkan potensi yang ada.

Penerapan buku panduan TPA HI berbasis alam memiliki factor pendukung dan penghambat. Factor pendukung antara lain: 1) memperoleh dukungan dari berbagai pihak, baik kepala sekolah, guru, orang tua dan anak. 2) memperoleh dukungan dari berbagai instansi sekitar TPA, seperti puskesmas, kepolisian, kelurahan dan kepariwisataan. 3) ketersediaan anggaran sarana prasarana PAUD dari pemerintah. Adapun faktor penghambat penerapan model buku panduan TPA HI berbasis alam, antara lain: 1) keterbatasan kemampuan guru dalam mengelola TPA HI secara komprehensif, 2) keterbatasan anggaran yang digunakan untuk beberapa kegiatan TPA HI yang membutuhkan anggaran cukup banyak, 3) rendahnya intensitas guru dalam memanfaatkan alam sekitar sebagai media pembelajaran.

Kelebihan model TPA HI berbasis alam yang bisa dikembangkan antara lain: 1) bisa memanfaatkan alam sekitar sebagai media pembelajaran, 2) bisa memanfaatkan barang mati bisa menjadi hidup dan bernilai, 3) mengintegralkan berbagai aspek dan komponen dalam 1 keberlangsungan program kegiatan pembelajaran, 4) efisiensi waktu pelaksanaan program kegiatan TPA, 5) pembelajaran bisa dilaksanakan baik di dalam maupun di luar kelas secara terprogram.

Kelebihan tersebut senada dengan hasil penelitian (Dewi S. dkk, 2013) tentang program TPA HI, yang menunjukkan bahwa 1) pelayanan yang dapat diberikan pada PAUD holistik integratif ini dapat berupa layanan kesehatan mulai dari perawatan selama kehamilan sampai pasca melahirkan, kesehatan anak usia 0-6 tahun, pengetahuan gizi selama kehamilan sampai gizi untuk anak yang sedang tumbuh kembang, serta pendidikan untuk anak usia 0-6 tahun seperti stimulasi yang tepat untuk anak usia 0 - 6 tahun; 2) desain PAUD holistik integratif ini dapat dilakukan terintegrasi mulai dari pendaftaran, penimbangan, pemantauan tumbuh kembang, pelayanan gizi, serta pelayanan pendidikan serta kesehatan untuk anak usia dini.

Kelebihan model TPA HI berbasis alam pada point (1) tentang pemanfaatan alam sekitar sebagai media pembelajaran senada dengan hasil penelitian (Wulansari \& Sugito, 2016) bahwa ada perbedaan kualitas proses belajar yang signifikan antara model Model PBA dan pembelajaran konvensional, Model PBA dapat meningkatkan kualitas proses belajar anak karena model ini mengakomodasi karakteristik belajar anak. Komponen-komponen kurikulum sekolah alam mendekatkan peserta didik pada alam dengan menjadikan alam sebagai lingkungan belajar dalam kegiatan pembelajaran. 
Pada Point (3) tentang integrasi dalam berbagai aspek senada dengan penelitian (Ririn, 2012) keterlibatan guru, orangtua murid, dan komite sekolah dalam memajukan sekolah. Keterlibatan orangtua murid dengan mengundang orangtua murid saat pergantian tema dan komunikasi tentang perkembangan anak. Komite sekolah memberikan dukungan baik dana maupun tenaga saat pembelajaran di luar maupun kegiatan sosial. Sedangkan pada point (5) tentang pembelajaran bisa dilaksanakan baik di dalam maupun di luar kelas secara terprogram, juga senada dengan penelitian (Sunanik, 2018) bahwa pelaksanaan pembelajaran berbasis alam di TK Alam Al Azhar Kutai Kartanegara dilaksanakan dengan pembelajaran di dalam kelas (indoor learning) dan di luar kelas (out learning) yang bertujuan untuk meningkatkan pemahaman siswa dan menjadikan pembelajaran menjadi bermakna bagi anak.

\section{SIMPULAN}

Penelitian menghasilkan produk Kualitas Model Layanan TPA Holistik Inetgratif Berbasis Alam cukup memadai. Penelitian ini juga diujicobakan melalui dua tahap yaitu ujicoba kelompok kecil dan ujicoba lapangan. Secara keseluruhan, hasil rata-rata ujicoba kelompok kecil diperoleh nilai sebesar yaitu 73,33\% dan dengan kategori interpretasi setuju. Adapun hasil rata-rata ujicoba lapangan diperoleh nilai yang berbeda-beda, yaitu 1) pada TKA sebesar 88,67\% dengan kategori interpretasi sangat baik, 2) pada TKB sebesar 90\% dengan kategori interpretasi sangat baik, 3) pada TKA sebesar 88\% dengan kategori interpretasi sangat baik, 4) pada TKD sebesar $86 \%$ dengan kategori interpretasi sangat baik. Sehingga hasil keseluruhan sebesar 88,16 dengan kategori interpretasi sangat baik. Oleh karenanya, produk akhir dinilai sangat baik dan siap digunakan sebagai buku panduan layanan TPA HI dalam proses pembelajaran.

\section{UCAPAN TERIMA KASIH}

Terima kasih yang sebesar-besarnya penulis sampaikan kepada kedua orang tua, suami dan anak-anak serta teman-teman mahasiswa PPs PAUD Unnes Angkatan tahun 2018 yang telah memberikan dukungan serta bantuan dalam proses penelitian ini, penulis juga mengucapkan terima kasih kepada pihak-pihak terkait yaitu pengelola TPA beserta pengasuh dan orang tua / wali murid TPA Tunas Pertiwi Rembang Jateng.

\section{DAFTAR PUSTAKA}

Aprilia, L., \& Trihantoyo, S. (2018). Pembelajaran Berbasis Alam Dalam Membentuk Karakter Siswa Cinta Lingkungan Dan Berbasis Religi Islami Di Jenjang Sd Sekolah Alam AlIzzah Krian. Inspirasi Manajemen Pendidikan, 6(2), 1-8.

Chairilsyah, D. (2017). Pengelolaan Taman Penitipan Anak di TK FKIP. Journal of Education Research and Evaluation, 1(4), pp.292-299. https://doi.org/10.23887/jere.v1i4.12493

Dewi S., A. C., Zahraini, D. A., \& Sabarini, S. (2013). Desain Pengembangan Anak Usia Dini Holistik Integratif PAUD Non Formal (Penelitian Research and Development di Pos PAUD Mutiara Kelurahan Lamper Lor Kecamatan Semarang Selatan). Jurnal Penelitian PAUDIA, 2(1), 105-126.

Hamdiani, Y., A., D. H. S., \& Basar, G. G. K. (2016). Layanan Anak Usia Dini/Prasekolah Dengan "Full Day Care" Di Taman Penitipan Anak. Prosiding Penelitian Dan Pengabdian Kepada Masyarakat, 3(2), 285-291. https:// doi.org/10.24198/jppm.v3i2.13694

Java, B. C. (2014). Integrative Holistic Development Program in School Integral Hidayatullah Yaa Bunayya Batang. Indonesian Journal of Early Childhood Education Studies, 3(1), 41-48. https:/ / doi.org/10.15294/ijeces.v3i1.9473

Kamtini. (2015). Pendidikan Anak Usia Dini Bagi Ibu Yang Bekerja Di Luar Rumah. Jurnal Pengabdian Kepada Masyarakat, 21(80), 45-50. 
DOI: 10.31004/obsesi.v6i4.2269

Khasanah, U. (2017). Model Layanan Taman Penitipan Anak (Tpa) Di Tpa Adni Islamic English School Surabaya. J+Plus Unesa, 6(1), 1-7.

Lestari, P. I., Prima, E., Putu, N., \& Sulistyadewi, E. (2018). Di Tempat Penitipan Anak. November, 103-108.

Penyelenggaraan pembelajaran berbasis alam guna mengembangkan karakter kepemimpinan. (2016).

Ririn, L. (2012). Penerapan Metode Mathernal Reflektif Dalam Pembelajaran Berbahasa Pada Anak Tunarungu Di Kelas Persiapan Slb Negeri Semarang. Indonesian Journal of Early Childhood Education Studies, 1(2), 1-6. https:/ / doi.org/10.15294/ijeces.v1i2.9210

Rizkita, D. (2017). Pengaruh Standar Kualitas Taman Penitian Anak (Tpa) Terhadap Motivasi Dan Kepuasaan Orangtua (Pengguna) Untuk Memilih Pelayanan Tpa Yang Tepat. Early Childhood: Jurnal Pendidikan, 1(1), 28-43. https://doi.org/10.35568/earlychildhood.v1i1.46

Sunanik, S. (2018). Pembelajaran berbasis alam untuk anak usia dini di tk alam al azhar kutai kartanegara. Al-Madrasah: Jurnal Pendidikan Madrasah Ibtidaiyah, 3(1), 81-110. https://doi.org/10.35931/am.v0i0.71

Supsiloani, Puspitawati, \& Noviy, H. (2015). Jurnal Pendidikan Ilmu-Ilmu Sosial Eksistensi Taman Penitipan Anak dan Manfaatnya bagi Ibu Rumah Tangga yang Bekerja ( Studi Kasus di TPA Dharma Asih Kota Medan ). Jurnal Pendidikan Ilmu-Ilmu Sosial, 7(2), 119-124. https:// doi.org/10.24114/jupiis.v7i2.3117

Wulansari, B. Y., \& Sugito, S. (2016). Pengembangan model pembelajaran berbasis alam untuk meningkatkan kualitas proses belajar anak usia dini. Jurnal Pendidikan Dan Pemberdayaan Masyarakat, 3(1), 16. https:// doi.org/10.21831/jppm.v3i1.7919 